\title{
A synthesis of gynandromorphy among wild bees (Hymenoptera: Apoidea), with an annotated description of several new cases
}

\author{
Denis Michez ${ }^{(1)}$, Pierre Rasmont ${ }^{(1)}$, Michaël Terzo $^{(1)} \&$ Nicolas J. Vereecken ${ }^{(2)}$ \\ (1) Laboratoire de Zoologie, Université de Mons (UMons), Place du Parc 20, B-7000 Mons, Belgique \\ (2) Evolution Biologique et Ecologie, CP 160/12, Université Libre de Bruxelles (ULB), Avenue F.D. Roosevelt 50, B-1050 Bruxelles, Belgique
}

\begin{abstract}
We here describe six new specimens of gynanders (i.e. specimens where male and female phenotypic characters occur on the same individual) from distinct families of wild bees (Hymenoptera, Apoidea). The newly described cases include Melitta haemorrhoidalis (Fabricius 1775) (Melittidae), Dasypoda hirtipes (Fabricius 1775) (Melittidae), Anthophora plumipes (Pallas 1772) (Apidae), Bombus monticola rondoui Vogt 1909 (Apidae), Bombus vestalis vestalis (Fourcroy 1785) (Apidae) and Bombus vestalis sorgonis (Strand 1917) (Apidae). Descriptions are accompanied by behavioural observations of gynanders under natural conditions before their capture for two cases. We also list 109 gynanders already described in bees and we interpret the newly described cases along these previous records. The putative origins of gynandromorphy are then discussed in the light of recent advances in the field of sex determination in Hymenoptera.
\end{abstract}

Résumé. Une synthèse sur la gynandromorphie des abeilles sauvages (Hymenoptera : Apoidea), avec la description commentée des plusieurs cas nouveaux. Nous décrivons dans le présent article six nouveaux spécimens de gynandromorphes (individu entier présentant à la fois des caractères morphologiques mâle et femelle) de plusieurs familles d'abeilles sauvages. Ces spécimens appartiennent aux espèces suivantes: Melitta haemorrhoidalis (Fabricius 1775) (Melittidae), Dasypoda hirtipes (Fabricius 1775) (Melittidae), Anthophora plumipes (Pallas 1772) (Apidae), Bombus monticola rondoui Vogt 1909 (Apidae), Bombus vestalis vestalis (Fourcroy 1785) (Apidae) et Bombus vestalis sorgonis (Strand 1917) (Apidae). Les descriptions sont complétées par des observations de comportement dans la nature pour deux spécimens avant leur capture. Par ailleurs, nous avons recensé 109 spécimens d'abeilles gynandromorphes déjà décrits dans la littérature ce qui nous permet d'interpréter les six nouveaux cas observés. Nous concluons cet article par une discussion sur les causes probables des phénomènes de gynandromorphie à la lumière des récentes découvertes réalisées dans le domaine de la détermination du sexe chez les Hyménoptères.

Keywords: Morphology, sex determination, Apoidea, gynandromorphy, deviant.

$\mathrm{A}_{\mathrm{t}}^{\mathrm{lt}}$ though environmental conditions might influence the sexual phenotypic outcome in animals lacking sex chromosomes (for evidence in reptiles see e.g. Bull 1980; Janzen \& Paukstis 1991a, 1991b; Ciofi \& Swingland 1997), sex phenotype is usually primarily genotypic-dependent and is determined by internal factors such as gonodal hormone secretions (Agate et al. 2003) and sex chromosomes (Crozier 1977; Hunt \& Page 1994; Beye \& Moritz 1994; Hunter 1995).

It has long been reported that sex determination in Hymenoptera was exclusively achieved through a peculiar mode called haplo-diploidy (or arrhenotoky) (review see Heimpel \& de Boer 2008). According to this model, females are diploid and develop from fertilised eggs, whereas males are haploid and develop

E-mail: denis.michez@umons.ac.be, pierre.rasmont@umons.ac.be, michael.terzo@skynet.be, nicolas.vereecken@ulb.ac.be Accepté le 14 juin 2009 from unfertilised ovules. The genetic mechanism underlying sex determination in these insects has received much attention over the past few decades and is now becoming better understood, especially in the honeybee. As far as most Hymenoptera and bees in particular are concerned, sex phenotypes are determined by allelic variation at a so-called "single locus of complementary sex determination" (sl-CSD) (Wilgenburg et al. 2006). This mechanism implies that females bees are heterozygotes $\left(A_{I_{2}} A_{2}\right)$, whereas males are hemizygotes $\left(A_{1}\right.$ or $A_{2}$ ) (Whiting 1933, 1943; Crozier 1977; Bull 1981; Cook \& Crozier 1995; Heimpel $\&$ de Boer 2008). Numerous cases of diploid males have been reported all across the order Hymenoptera (Whiting \& Whiting 1925; Duchâteau et al. 1994; Pamilo et al. 1994; Cook \& Crozier 1995; Zayed $\&$ Packer 2001). This unusual, or perhaps underreported phenomenon (see e.g. Liebert et al. 2004), is made possible via homozygosity $\left(A_{1} A_{1}\right.$ or $\left.A_{2} A_{2}\right)$ at the aforementioned sex-determining locus (Cook \& Crozier 1995; Wilgenburg et al. 2006). 


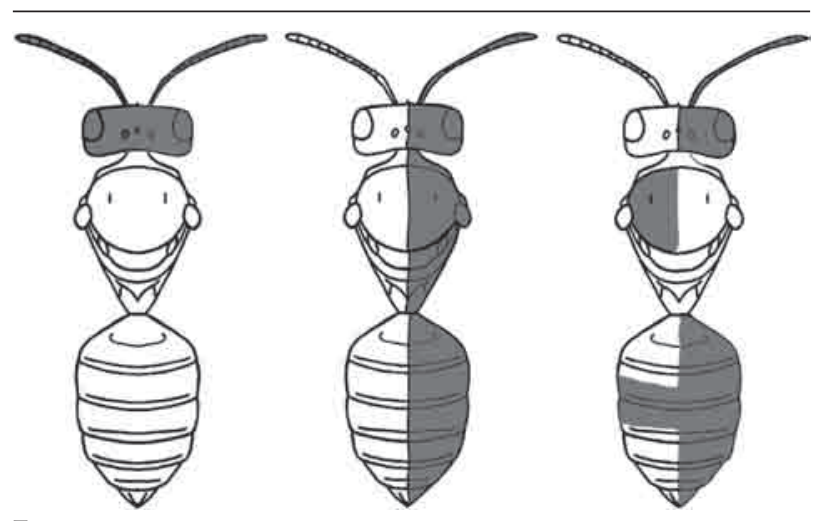

Figure 1

Schematic representation of an example of the three major categories of gynandromorphy: transversal (left), bilateral (centre), and mosaic (right). Male tissues are drawn in grey, female tissues are white.

The recent insights in this field of research have also allowed drawing new perspectives in some related areas of sex determination such as the possible mechanisms driving the rise of teratologies (morphological abnormalities) among the Hymenoptera. Gynandromorphy is one of the best known cases of teratology. Numerous reports and descriptions have been made of so-called $g y$ nanders ["condition in which male and female features are displayed in one individual' (Gordh \& Headrick 2001)], especially in Chalcidoidea (Pintureau et al. 1999), Formicidae (Hall \& Smith 1954; Berndt \& Kremer 1983), Mutillidae (Wheeler 1910), Pompilidae (Wolf 1989; Wahis 1996) and Vespidae (Cooper 1959). This phenomenon is also well described in Apoidea with some authors like Wolf having displayed tremendous endeavour in describing new cases of gynandromorphy during the past two decades (Wolf 1982 to 2000, see all references in tab. 6).
This paper proposes an annotated description of six new cases of gynandromorphy with behavioural observations for two cases. The origin of gynandromorphism among Apoidea is then discussed in the light of both past and recent reports in the field of sex determination in Hymenoptera.

\section{Material and Methods}

\section{Description of new gynanders}

The gynander of Dasypoda hirtipes (Fabricius 1793) was collected on 26.VI.2003 in a wide nesting site encompassing hundreds of nests in activity at Erbisoeul, Belgium $\left(50^{\circ} 30^{\prime} 33^{\prime \prime} \mathrm{N}\right.$ 035'20”E, WGS, leg. D. Michez). The gynander of Bombus monticola rondoui Vogt 1909 was collected on 18.VII.2000 foraging on Rhododendron ferrugineum L. (Ericaceae) at Evol, France ( $43^{\circ} 38^{\prime} 07^{\prime \prime} \mathrm{N} 06^{\circ} 12^{\prime} 48^{\prime \prime} \mathrm{E}$, WGS, leg. P. Rasmont). Both of these bees were killed with ethyl-acetate and set on an insect pin. The genitalia and internal sterna were then extracted from the metasoma and dissected for additional observations on morphological characters.

Four others gynanders of Melitta haemorrhoidalis (Fabricius 1775), Anthophora plumipes (Pallas 1772), Bombus vestalis vestalis (Fourcroy 1785) and Bombus vestalis sorgonis (Strand 1917) were found in the collections of the Naturhistorisches Museum Wien (NMW, Austria), the Natural History Museum of London (NHM, UK) and the University of Mons-Hainaut (UMH, Belgium). The gynander of $M$. haemorrhoidalis was caught on 09.IX.1855 in Villa Opicina (Italia, Friuli-Venezia Giulia, $45^{\circ} 41^{\prime} \mathrm{N} 13^{\circ} 47^{\prime} \mathrm{E}$, WGS, leg. Graeffe) foraging on Campanula sp. (NMW, Graeffe collection). The gynander of A. plumipes was caught on 09.V.1975 in Hundon (England, Suffolk, $52^{\circ} 06^{\prime} \mathrm{N} 00^{\circ} 33^{\prime} \mathrm{E}$, WGS leg. Chinery), foraging on garden flowers (NHM, Main collection). The gynander of $B$. vestalis sorgonis was caught on 05.VII.1984 in Sassari, Mont Limbara (Italia, Sardinia, $40^{\circ} 51^{\prime} \mathrm{N} 09^{\circ} 10^{\prime} \mathrm{E}$, leg. R. De Jonghe) (UMH). The gynander of $B$. vestalis vestalis was caught on

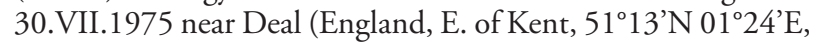
WGS, leg. G. Else) (NHM, Else collection).
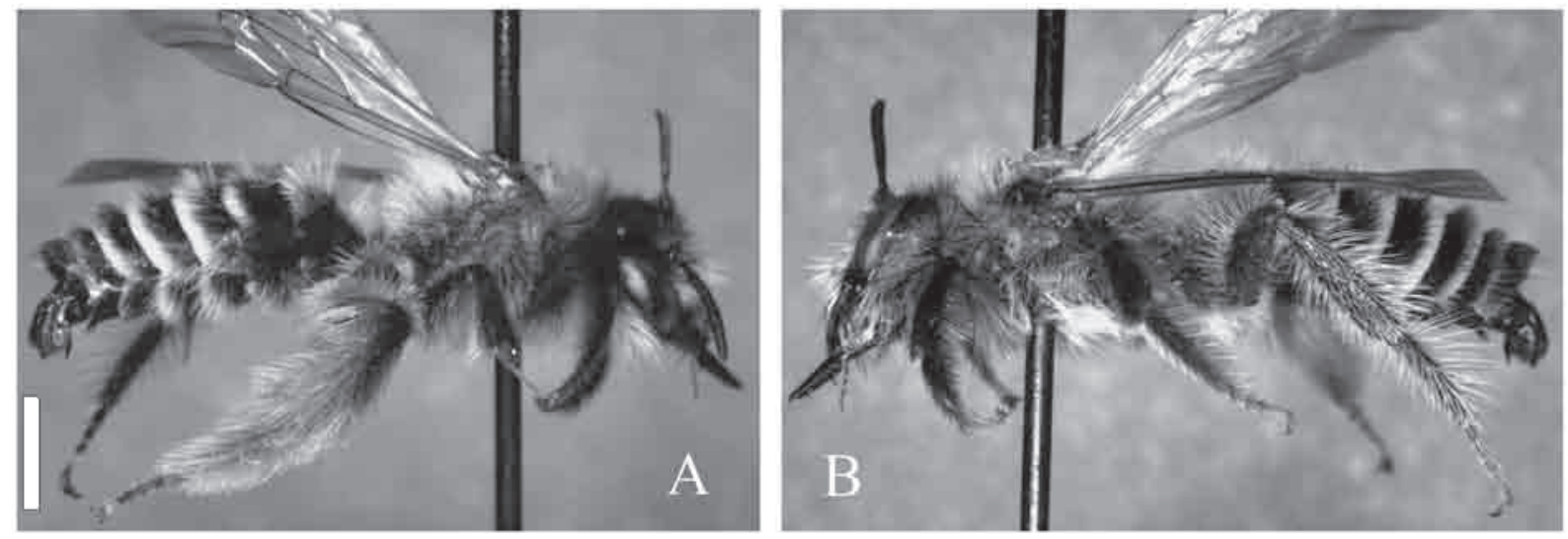

Figure 2

Dasypoda hirtipes gynander. A, left profile; $\mathbf{B}$, right profile (scale $=0.3 \mathrm{~mm}$ ). 
Table 1. Comparison of characters displayed by both sexes of Melitta haemorrhoidalis to those of the gynander.

\begin{tabular}{|c|c|c|c|}
\hline Character & Female & Male & Gynander \\
\hline \multicolumn{4}{|l|}{ Prosoma } \\
\hline Clypeus & Unpunctate medially & Punctate completely & q \\
\hline Antenna & 12 segments & 13 segments & q \\
\hline Vertex vestiture & Black & Yellowish & q \\
\hline \multicolumn{4}{|l|}{ Mesosoma } \\
\hline Scutum vestiture & Black & Brown & Right half part + , left half part $\delta^{\lambda}$ \\
\hline Legs vestiture & Brown & Yellowish & Right half part $q$, left half part $\delta$ \\
\hline Posterior leg & With enlarged basitarsus and scopa & Without enlarged basitarsus and scopa & Right half part $q$, left half part $\delta$ \\
\hline \multicolumn{4}{|l|}{ Metasoma } \\
\hline Exposed sterna & 6 & 8 & $\overline{0}$ \\
\hline Disc of terga & Hairless & With erected yellowish setae & 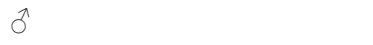 \\
\hline Sting & Present & Absent & 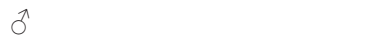 \\
\hline Sclerotized genitalia & Absent & Present & 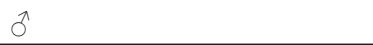 \\
\hline
\end{tabular}

\section{Review of the literature on gynandromorphy in Apoidea}

Each description of an Apoidea gynander found in the literature was examined and classified (when possible) into one of the three commonly accepted gynander categories: (i) bilateral if female and male body parts are equal and symmetric, (ii) transverse if sex characters are distributed in two asymmetrical parts; (iii) mosaic if sex characters are distributed randomly in the body (fig. 1). The results of this survey are reported in tab. 6 . The generic classification and the morphological nomenclature reported in tabs. 1-6 follow Michener (2000).

\section{Results}

\section{Description of the Melitta haemorrboidalis gynander}

Male and female tissues are distributed on two distinct areas of the body (tab. 1). The head and right part of the mesosoma present female features. The left part of the mesosoma and the metasoma present male features. These characteristics lead us to conclude that the $M$. haemorrhoidalis gynander falls within the transverse gynander category.

Table 2. Comparison of characters displayed by both sexes of Dasypoda hirtipes to those of the gynander.

\begin{tabular}{|c|c|c|c|}
\hline Character & Female & Male & Gynander \\
\hline \multicolumn{4}{|l|}{ Prosoma } \\
\hline Clypeus & Irregularly rounded & Regularly rounded & $q$ \\
\hline Antenna & 12 segments & 13 segments & o \\
\hline Vertex vestiture & Black & Red & q \\
\hline \multicolumn{4}{|l|}{ Mesosoma } \\
\hline Ventral side vestiture & Brown & White & $q$ \\
\hline $\begin{array}{l}\text { Fore }(a) \text { and hind }(p) \text { legs } \\
\text { vestiture }\end{array}$ & Brown (a) and red (p) & $\operatorname{Red}(a$ and $p)$ & q \\
\hline Hind leg & Exhibiting scopae & Without scopae & Right + , left $\widehat{\partial}$ \\
\hline \multicolumn{4}{|l|}{ Metasoma } \\
\hline Exposed sterna & 6 & 8 & 8 \\
\hline Sterna vestiture & Black & Red & Red \\
\hline Exposed terga & 6 & 7 & 7 \\
\hline Tergum 2 & $\begin{array}{l}\text { Strip of white hairs at the apex of the } \\
\text { uninterrupted terga in the median } \\
\text { zone; curved black hairs at its bottom }\end{array}$ & $\begin{array}{l}\text { Strip of reddish hairs at the apex of } \\
\text { the uninterrupted terga and tousled } \\
\text { red hairs }\end{array}$ & Right half part + , left half part $\delta^{\lambda}$ \\
\hline Other terga & $\begin{array}{l}\text { Strip of white hairs at the apex of the } \\
\text { uninterrupted terga in the median } \\
\text { zone; curved black hairs at its bottom }\end{array}$ & $\begin{array}{l}\text { Strip of reddish hairs at the apex of } \\
\text { the uninterrupted terga and tousled } \\
\text { red hairs }\end{array}$ & $\sigma^{\pi}$ \\
\hline Sting & Present & Absent & Absent \\
\hline Sclerotized genitalia & Absent & Present & Present \\
\hline
\end{tabular}


Table 3. Comparison of characters displayed by both sexes of Anthophora plumipes to those of the gynander.

\begin{tabular}{|c|c|c|c|}
\hline Character & Female & Male & Gynander \\
\hline \multicolumn{4}{|l|}{ Prosoma } \\
\hline Cuticle & Black & $\begin{array}{l}\text { Mandibles, labrum, clypeus, paraclypeal area, supraclypeal } \\
\text { area and scape with yellow spots }\end{array}$ & $\underset{\delta}{\text { Right half part } q \text {, left half part }}$ \\
\hline Vestiture & Black & With white setae and some black setae (mainly on vertex) & $\mathrm{R}_{\partial}^{\lambda}$ ight half part $q$, left half part \\
\hline Antenna & 12 segments & 13 segments & 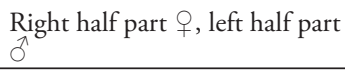 \\
\hline \multicolumn{4}{|l|}{ Mesosoma } \\
\hline Vestiture & Black & Ventral face with reddish setae & Right half part + , left half part \\
\hline Anterior leg & With black setae & Mainly with white setae & Right + , left $\hat{\sigma}$ \\
\hline Median leg & With short setae & With long setae & Right $q$, left $\widehat{\partial}$ \\
\hline Posterior leg & With scopae & Without scopae & Right + , left $\hat{\sigma}$ \\
\hline \multicolumn{4}{|l|}{ Metasoma } \\
\hline Vestiture & Black & White & q \\
\hline
\end{tabular}

\section{Description of the Dasypoda birtipes gynander}

Male and female tissues are distributed patchily (fig. 2, tab. 2). Altogether, the prosoma, the mesosoma and five out of six legs exhibit female characters. Both the whole metasoma (including the genitalia) and the left hind leg show typical male features. The right half of the second metasomal terga displays female vestiture. These characteristics lead us to conclude that the $D$. hirtipes gynander falls within the mosaic gynander category.

The specimen was observed digging actively on the nesting site, thereby displaying exactly the same behaviour as that of conspecific mated females provisioning their brood cells with pollen and nectar (Lind 1968). Male Apoidea are known to devote most of their time searching for mates and feeding on co-occurring flower patches (Eickwort \& Ginsberg 1980). They have never been observed engaging in the construction of the nest.

\section{Description of the Anthophora plumipes gynander}

Male and female tissues are distributed on two distinct areas of the body (tab. 3). The left half-part of the head, the left half part of the mesosoma and the left legs 1-2 present male features. Others parts of the body are female. These characteristics lead us to conclude that the $A$. plumipes gynander falls within the transverse gynander category.

\section{Description of the Bombus monticola rondoui gynander}

Secondary sexual characters are symmetrically distributed on the left (male) and on the right (female) half of the body (figs 3A-E, tab. 4). Of particular interest is the close examination of the internal sclera: the left part bears typical female characteristics, the right part is composed of an hemi-male genitalia showing

Table 4. Comparison of characters displayed by both sexes of Bombus monticola rondoui.

\begin{tabular}{|c|c|c|}
\hline Character & $\begin{array}{c}\text { Female } \\
\text { (right part of gynander) }\end{array}$ & $\begin{array}{c}\text { Male } \\
\text { (left part of gynander) }\end{array}$ \\
\hline \multicolumn{3}{|l|}{ Prosoma } \\
\hline Mandible & Wide; no barbae mandibularis & Narrow; barbae mandibularis present \\
\hline Antenna & 12 segments & 13 segments \\
\hline Face, vertex and clypeus vestiture & $\begin{array}{l}\text { Black hairs with some brownish bristles on the inner } \\
\text { margin }\end{array}$ & $\begin{array}{l}\text { Dense and yellowish vestiture on the inner side; dense and } \\
\text { black vestiture on the outer side }\end{array}$ \\
\hline Labrum & Wide & Narrow \\
\hline \multicolumn{3}{|l|}{ Mesosoma } \\
\hline Thorax vestiture & Collar down to the coxa & Collar stops before the coxa \\
\hline Posterior legs & Scopa and pollen comb present; basitarsus enlarged & No scopa or pollen comb; basitarsus thin \\
\hline $\begin{array}{l}\text { Vestiture of the inner face of the } \\
\text { median basitarsus }\end{array}$ & Red to brown on the apical half & Reddish (bristles) on its whole length \\
\hline \multicolumn{3}{|l|}{ Metasoma } \\
\hline Sterna vestiture & Small and white & Long and white \\
\hline Genitalia & Absent & Present \\
\hline Sting and sheath lobe & Present & Absent \\
\hline
\end{tabular}


a single penis valve and a single gonostylus (figs 3F-G). These characteristics lead us to conclude that the $B$. monticola gynander ranks within the bilateral gynander category

The B. monticola gynander was caught on a Rhododendron ferrugineum while it was collecting pollen the same way as normal workers do. The specimen was only able to collect pollen using its left hind leg which bore a pollen comb.

\section{Description of the Bombus vestalis sorgonis gynander}

Male and female tissues are distributed on two distinct areas of the body (tab. 5). The right half of the head and of the mesosoma (including legs) present male features. Others parts of the body are female. These characteristics lead us to conclude that the $B$. vestalis sorgonis gynander falls within the transverse gynander category.

\section{Description of the Bombus vestalis vestalis gynander}

Male and female tissues are distributed patchily (tab. 5). Altogether, both mandibles, left half part of the labrum, left half part of the face, right antenna, right half part of the vertex, left half part of the mesosoma and right half part of the metasoma exhibit male characters. Others parts of the body show typical male features. These characteristics lead us to conclude that the $B$. vestalis vestalis gynander falls within the mosaic gynander category.
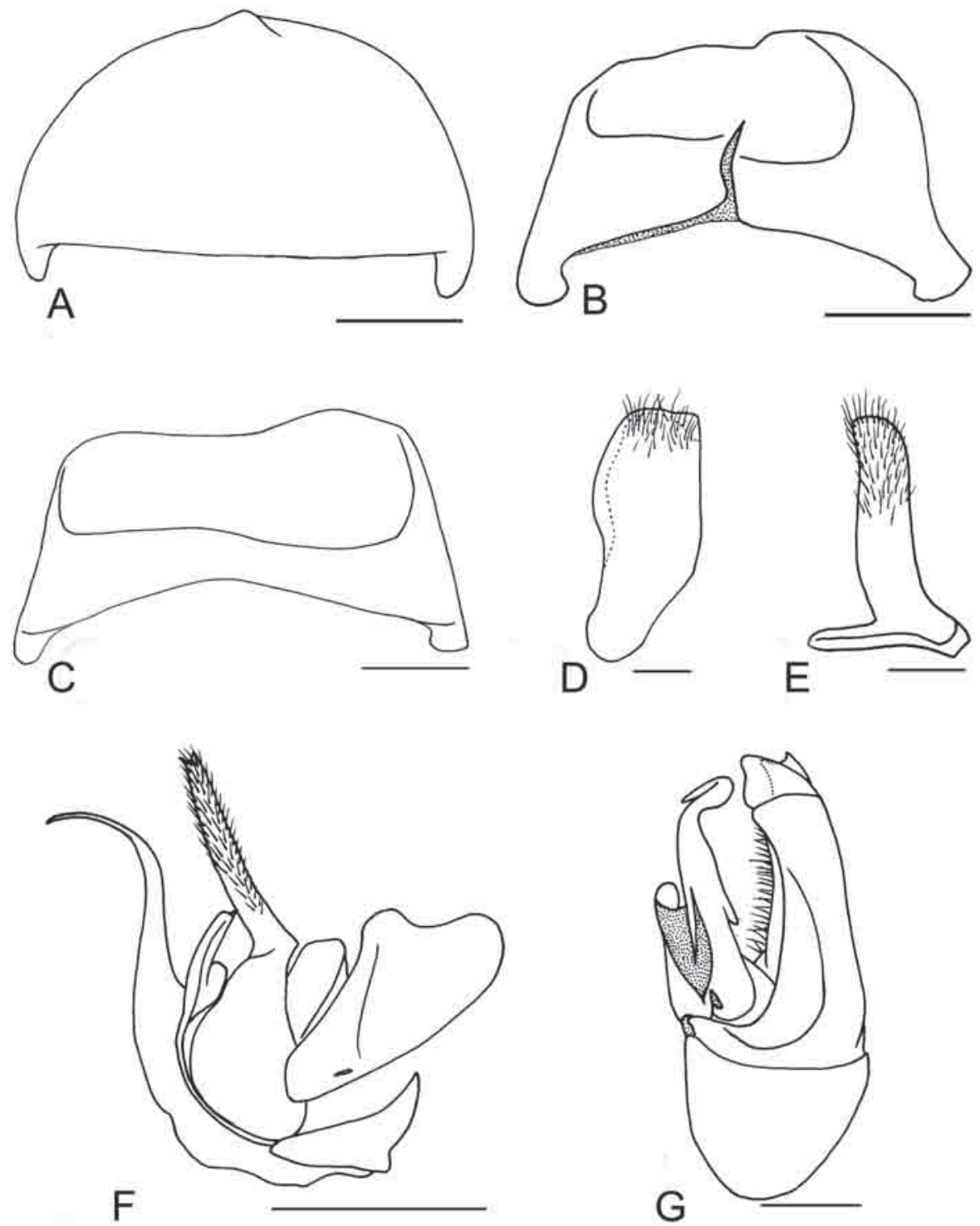

Figure 3

Bombus monticola gynander. A, $8^{\text {th }}$ tergum, front view (scale $\left.=1 \mathrm{~mm}\right) ; \mathbf{B}, 6^{\text {th }}$ sternum, front view $($ scale $=1 \mathrm{~mm}) ; \mathbf{C}, 7^{\text {th }}$ sternum, front view; $\mathbf{D}, 7^{\text {th }}$ sternum, lateral view $($ scale $=0.5 \mathrm{~mm}) ; \mathbf{E}, 8^{\text {th }}$ sternum, front view $($ scale $=1 \mathrm{~mm}) ; \mathbf{F}$, right part of genitalia $($ scale $=1 \mathrm{~mm}) ; \mathbf{G}$, left part of genitalia $(\mathrm{scale}=0.5 \mathrm{~mm})$. 
Table 5. Comparison of characters displayed by both sexes of Bombus vestalis sorgonis and Bombus vestalis vestalis to those of the gynander.

\begin{tabular}{|c|c|c|c|c|}
\hline Character & Female & Male & $\begin{array}{l}\text { Gynander of } \\
\text { B. v. sorgonis }\end{array}$ & $\begin{array}{l}\text { Gynander of } \\
\text { B. v. vestalis }\end{array}$ \\
\hline \multicolumn{5}{|l|}{ Prosoma } \\
\hline Mandible & $\begin{array}{l}\text { Wide; no barbae } \\
\text { mandibularis }\end{array}$ & $\begin{array}{l}\text { Narrow; barbae mandibularis } \\
\text { present }\end{array}$ & Right $\hat{\partial}$, left $q$ & Both $\sigma^{1}$ \\
\hline Labrum & Wide & Narrow & Right half part $\hat{\partial}$, left half part $\phi$ & Right half part $q$, left half part $\widehat{\partial}$ \\
\hline Face & With short setae & With long setae & Right half part $\delta^{\lambda}$, left half part $q$ & Right half part $q$, left half part $\delta$ \\
\hline Vertex & With black setae & With black and yellow setae & Right half part $\hat{\delta}$, left half part $\phi$ & Right half part $\hat{\delta}$, left half part $q$ \\
\hline Antennae & 12 segmented & 13 segmented & Right $\hat{\partial}$, left + & Right $\hat{\partial}$, left abnormal \\
\hline \multicolumn{5}{|l|}{ Mesosoma } \\
\hline Collare & Black & With black and yellow setae & Right half part $\delta^{\lambda}$, left half part $q$ & Right half part $q$, left half part $\delta$ \\
\hline Scutellar & Black & With back and yellow setae & Right half part $\delta$, left half part $\phi$ & Right half part $q$, left half part $\delta$ \\
\hline Posterior leg & Basitarsus enlarged & Basitarsus thin & Right $\hat{O}$, left $q$ & Right + , left $\widehat{\partial}$ \\
\hline \multicolumn{5}{|l|}{ Metasoma } \\
\hline Genitalia & Present & Absent & q & Right part $\hat{\partial}$, left part $\hat{\partial}$ \\
\hline Sting and sheath lobe & Present & Absent & q & Right part $\hat{\partial}$, left part $\hat{\partial}$ \\
\hline
\end{tabular}

\section{Review of the literature on gynandromorphy in Apoidea}

A total of 109 reports of gynandromorphy among Apoidea have been described so far in 6 bee families (tab. 6). Analysing the relative proportion of each gynander category found in the literature reveals that transverse gynanders are by far the most frequently reported cases (61 out of 109 , i.e. $56 \%$ ), followed by mosaic gynanders (38 out of 109 , i.e. $33 \%$ ), and by the very few cases of bilateral gynanders (10 out of 109 , i.e. $9 \%)$.

\section{Discussion}

Three major hypotheses have been advanced since the early twentieth century to explain the causes of gynandromorphy, namely (i) embryonic fertilisation (Boveri 1915), (ii) polyspermy (Morgan 1916) and (iii) chromosome elimination (Morgan $\&$ Bridges 1919). The validity of these hypotheses has been thoroughly explored experimentally by Rothenbuhler (1958), who investigated the genetic mechanisms driving the rise of gynandromorphy using Apis mellifera L. as model species (fig. 4A). Rothenbuhler (1958) reported that a great deal of the gynanders obtained displayed father-inherited, haploid characters on the "male" body parts. These first results supported Morgan's (1916) early hypothesis of polyspermy as the predominant mechanism causing gynandromorphy to occur. Under this scenario, the fertilised nuclei produce diploid (female) characters, while the second sperm nucleus remain haploid and result in "male" body parts (fig. 4B).

This hypothesis showed its limitations when attempting to explain how other phenotypes could have been produced, such as gynanders with motherinherited, haploid characters on the "male" body parts (fig. 4C). The most plausible alternative hypothesis accounting for such phenotypic abnormalities was first proposed by Boveri (1915) and concerned the phenomenon of partial fertilisation, in which the sperm is "delayed from penetrating ooplasm until cleavage commences" (Gordh \& Headrick 2001). Resulting from this is the production of an embryo with fertilised nuclei becoming diploid "female" characteristics, whereas unfertilised nuclei become mother-inherited "male" tissues (fig. 4C).

The chromosome elimination hypothesis is supported by the production of specimens showing male and female diploid characters (fig. 4D-E). But Rothenbuhler (1958) remained puzzled about his observations on males displaying diploid characters, as witnessed by the question mark on the illustration of his original paper. At this time CSD and diploid males were well not understood. It is only during the past decade that studies have focused more precisely on diploid male production among Hymenoptera (see e.g. Stouthamer et al. 1992; Cook 1993; Duchâteau et al. 1994; Cook \& Crozier 1995; Zayed \& Packer 2001; Cowan \& Stahlhut 2004). How diploid males arise is now well known (at least in honeybee): haploid males are CSD hemizygous while diploid males are commonly CSD homozygous (Cook \& Crozier 1995). In gynandromorphs showing female and male diploid characters (figs 4D-E), female parts have to be CSD heterozygous while male tissues should be (i) CSD hemizygous or (ii) CSD homozygous. The former hypothesis (i) implies the loss of chromosome bearing CSD and correspond to the chromosome elimination hypothesis (Rothenbuhler 1958; Gordh \& Headrick 
2001). This process might take place during the stage of zygote cell division, whenever a daughter nucleus loses the chromosome bearing the CSD although the genetic cell contents is double that of all other remaining loci (Fig. 4D). The latter hypothesis (ii) implies mutation and/or inhibition that inactivate or remove part of the CSD allele but not whole chromosome (Fig. 4E). This hypothesis has not yet been proposed to explain gynandromorphism but recent studies show that repression of the CSD transcript effectively results in male traits in honeybee (Beye et al. 2003).

In light of the above scenarios for the origin of gynandromorphy, we may formulate hypotheses concerning the developmental pathways leading to the formation of the gynanders observed among wild bees (Tabs. I-VI). First, mosaic gynanders (e.g. presently described Dasypoda hirtipes and Bombus vestalis vestalis) can be the immediate outcome of some independent chromosomal aberration, elimination or characteristic of CSD expression within distinct embryonic tissues during the development of the embryo (figs 4D-E). Second, transverse gynander (e.g. presently described Melitta haemorrhoidalis, Anthophora plumipes and Bombus vestalis sorgonis) and bilateral gynander (e.g. presently described Bombus monticola rondoui) result from an unique genetic accident. Bilateral gynander could result from any of the proposed developmental pathways (figs $4 \mathrm{~B}-\mathrm{E}$ ) while a single alteration of CSD is more likely for transversal gynander (late polyspermy or embryonic fertilisation seem unlikely). Modern molecular techniques such as flow cytometry represent appropriate tools to check the ploidy level of specimen

A
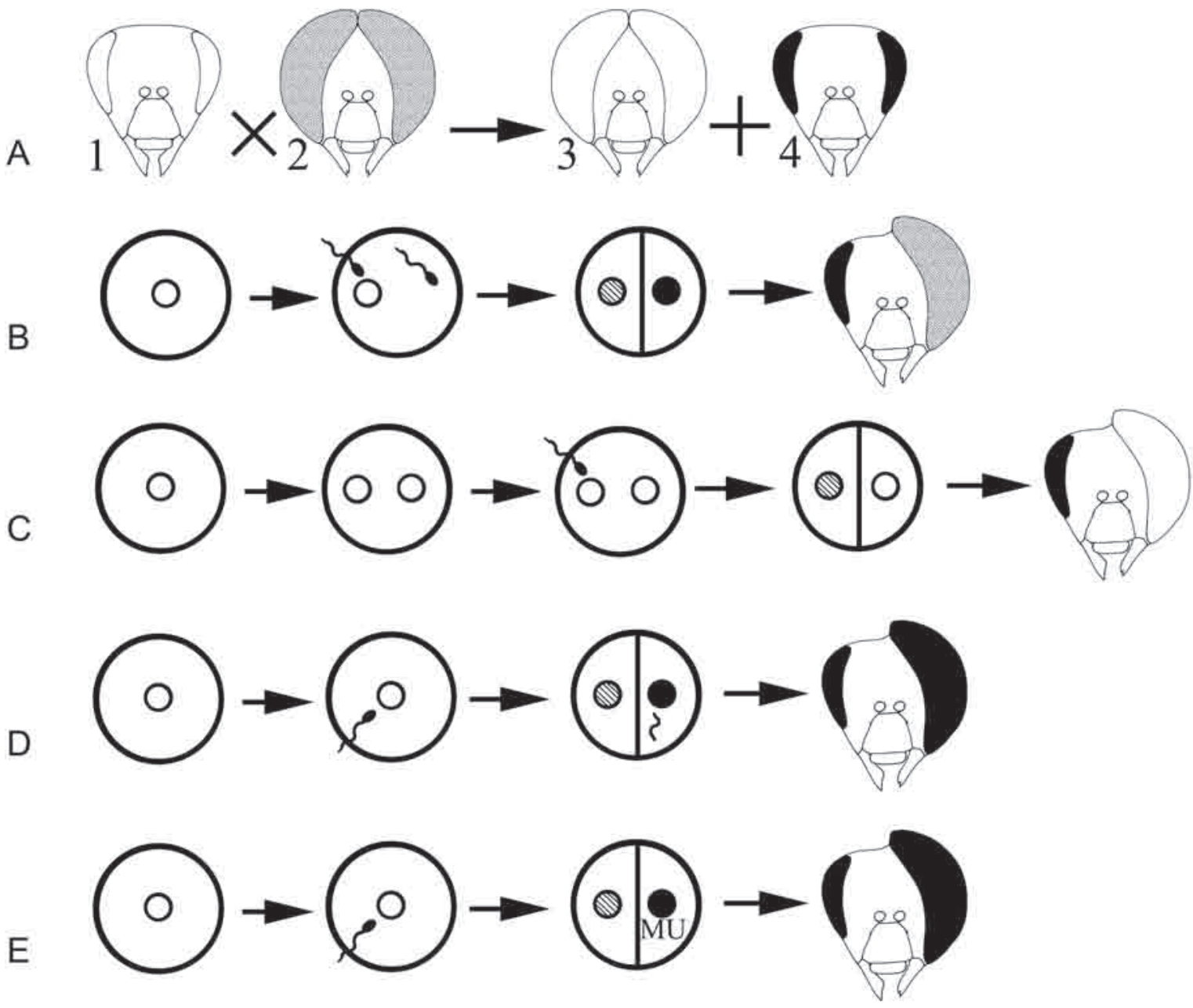

Figure 4

Testing hypotheses of Rothenbuhler (1958). A, mating experience ( 1 = Female ivory eye recessive character; 2 = Drone chartreuse eye recessive character; 3 = Drone ivory eye; 4 = Normal diploid progeny); B-D, phenotypes of obtained gynandromorph and hypothesis of origin: B, embryonic fertilisation; C, polyspermy; D, chromosome elimination. 
Table 6. Cases of gynandromorphy reported from Apoidea

\begin{tabular}{|c|c|c|}
\hline Species described & $\begin{array}{l}\text { Gynander } \\
\text { Category }^{1}\end{array}$ & Reference \\
\hline \multicolumn{3}{|l|}{ APIDAE } \\
\hline Anthophora furcata (Panzer) & $\operatorname{Tr}$ & Wolf (1995a) \\
\hline Bombus fernaldae (Franklin) & Mo & Milliron (1960) \\
\hline B. flavifrons Cresson & Mo & Milliron (1962) \\
\hline B. lapidarius (L.) & $\mathrm{Tr}, \mathrm{Mo}$ & $\begin{array}{l}\text { Sichel (1858), } \\
\text { Stöckhert (1920) }\end{array}$ \\
\hline B. pascuorum (Scopoli) & $\mathrm{Bi}, 2 \mathrm{Tr}$ & $\begin{array}{l}\text { Röseler (1962), } \\
\text { Laidlaw (1932), Wolf } \\
\text { (1993b) }\end{array}$ \\
\hline B. pratorum (L.) & $\operatorname{Tr}$ & Wolf (1991b) \\
\hline B. monticola Smith & $\mathrm{Bi}$ & Present study \\
\hline B. ruderarius Müller & Mo & Stöckhert (1924) \\
\hline B. wurflenii Radoskowski & Bi, Mo & $\begin{array}{l}\text { Ritsema (1881), } \\
\text { Stöckhert (1924) }\end{array}$ \\
\hline Epeolus julliani Pérez & $\operatorname{Tr}$ & Wolf (2000) \\
\hline Partamona cupira Smith & $\operatorname{Tr}$ & Schwarz (1929) \\
\hline Nomada fucata Panzer & Mo & Schenk (1871) \\
\hline Nomada sp. & $\operatorname{Tr}$ & Tsuneki (1975) \\
\hline N. laevilabris Schmiedecknecht & $\operatorname{Tr}$ & $\begin{array}{l}\text { Pérez-Iñigo Mora } \\
\text { (1982) }\end{array}$ \\
\hline Thyreus redaluctus? Cockerell & $\mathrm{Bi}$ & Engel (2007) \\
\hline Xylocopa brasilianorum (L.) & $\mathrm{Bi}$ & $\begin{array}{l}\text { Benoist \& Berland } \\
\text { (1935) }\end{array}$ \\
\hline$X$. confusa Pérez & $\operatorname{Tr}$ & Handschin (1935) \\
\hline$X$. fenestrata (Fabricius) & Mo & Maa (1940) \\
\hline X. mendozana Enderlein & $\mathrm{Bi}$ & Enderlein (1913) \\
\hline$X$. micans Lepeletier & $\operatorname{Tr}$ & Maidl (1912) \\
\hline$X$. nigrita (Fabricius) & $\operatorname{Tr}$ & Carcasson (1965) \\
\hline$X$. ordinaria Smith & Mo & Enderlein (1913) \\
\hline \multicolumn{3}{|l|}{ ANDRENIDAE } \\
\hline Andrena barbilabris (Kirby) & $\operatorname{Tr}$ & Wolf (1993b) \\
\hline A. bimaculata (Kirby) & Mo & Perkins (1914) \\
\hline A. convexiuscula Kirby & $\operatorname{Tr}$ & Schenk (1871) \\
\hline A. haemorrhoa (Fabricius) & $\operatorname{Tr}$ & Wolf (1989) \\
\hline A. fasciata Wesm. & $\operatorname{Tr}$ & Schenk (1871) \\
\hline A. flavipes Panzer & $\operatorname{Tr}$ & Perkins (1914) \\
\hline A. fucata Smith & $\operatorname{Tr}$ & Loken (1967) \\
\hline A. fulva (Müller) & $2 \operatorname{Tr}$ & Wolf $(1990,1993 a)$ \\
\hline A. helvola (L.) & $\mathrm{Tr}, \mathrm{Mo}$ & $\begin{array}{l}\text { Schenk (1871), Celary } \\
\& \text { Wisniowski (2001) }\end{array}$ \\
\hline A. humilis Imhoff & $\operatorname{Tr}, \operatorname{Tr}$ & $\begin{array}{l}\text { Wolf (1995b), Wolf } \\
\text { (1994b) }\end{array}$ \\
\hline A. potentillae Panzer & $\operatorname{Tr}$ & Wolf (1982) \\
\hline A. porterae Cockerell & Mo & Linsley (1937) \\
\hline A. praecox (Scopoli) & $\operatorname{Tr}$ & Wolf (1998c) \\
\hline \multicolumn{3}{|l|}{ COLLETIDAE } \\
\hline Colletes cunicularius (L.) & $\mathrm{Bi}$ & O’Toole (1989) \\
\hline Hylaeus albofasciata Friese & $\operatorname{Tr}$ & Stöckhert (1924) \\
\hline H. brevicornis Nylander & $\operatorname{Tr}$ & Morice (1915) \\
\hline H. minuta (Fabricius) & $\operatorname{Tr}$ & Noskiewicz (1923) \\
\hline Euryglossa sp. & $\operatorname{Tr}$ & Exley (1976) \\
\hline
\end{tabular}

\begin{tabular}{|c|c|c|}
\hline Species described & $\begin{array}{l}\text { Gynander } \\
\text { Category }^{1}\end{array}$ & Reference \\
\hline Dasypoda hirtipes (Fabricius) & Tr, Mo & $\begin{array}{l}\text { Wolf (1995a), present } \\
\text { study }\end{array}$ \\
\hline Melitta haemorrhoidalis (Fabricius) & Mo, $\operatorname{Tr}$ & $\begin{array}{l}\text { Wolf (1985), present } \\
\text { study }\end{array}$ \\
\hline \multicolumn{3}{|l|}{ HALICTIDAE } \\
\hline Halictus quadricinctus (Fabricius) & Mo & Saunders (1901) \\
\hline H. sexcinctus (Fabricius) & $\operatorname{Tr}$ & Leclercq (1953) \\
\hline H. tumulorum (L.) & $2 \mathrm{Tr}, \mathrm{Mo}$ & $\begin{array}{l}\text { Wolf (1995a), } \\
\text { Andrewes (1946), } \\
\text { Hohndorf (1931) }\end{array}$ \\
\hline Lasioglossum albipes (Fabricius) & Mo & Nilsson (1987) \\
\hline L. calceatum (Scopoli) & Mo & $\begin{array}{l}\text { Plateaux-Quénu \& } \\
\text { Plateau-Quénu (1982) }\end{array}$ \\
\hline L. eurygnathus Bluthgen & Mo & Popov (1937) \\
\hline L. fulvicorne (Kirby) & $\operatorname{Tr}$ & Wolf (1987a) \\
\hline L. lativentre (Schenck) & $\operatorname{Tr}$ & Stöckhert (1924) \\
\hline L. lissonotum (Noskiewicz) & $\operatorname{Tr}$ & Wolf (1990) \\
\hline L. malachurum (Kirby) & Mo & Stöckhert (1924) \\
\hline L. morio (Fabricius) & $\operatorname{Tr}$ & Wolf (1986) \\
\hline Nomioides minutissimus (Rossi) & Mo & Wolf (1997) \\
\hline Sphescodes albilabris (Fabricius) & Mo & Wolf (1994a) \\
\hline S. geofrellus (Kirby) & $\operatorname{Tr}$ & Wolf (1987b) \\
\hline S. niger Hagens & $\operatorname{Tr}$ & Wolf (1991b) \\
\hline S. reticulatus Thomson & $\operatorname{Tr}$ & Stöckhert (1924) \\
\hline S. rufiventris (Panzer) & $\operatorname{Tr}$ & Wolf (1987b) \\
\hline \multicolumn{3}{|l|}{ MEGACHILIDAE } \\
\hline Anthidium oblongatum Latreille & $\operatorname{Tr}$ & Stöckhert (1924) \\
\hline A. strigatum (Panzer) & Mo & Wolf (1998a) \\
\hline Chalicodoma parietina (Geoffroy) & $\mathrm{Bi}$ & $\begin{array}{l}\text { Bischoff \& Ulrich } \\
\text { (1929) }\end{array}$ \\
\hline Coelioxys inermis (Kirby) & $\operatorname{Tr}$ & Wolf (1999) \\
\hline C. rufescens Lepeletier & Mo & Noskiewicz (1923) \\
\hline Dianthidium ulkei (Cresson) & $\operatorname{Tr}$ & Schwarz (1926) \\
\hline D. sayi Cockerell & $\operatorname{Tr}$ & Hicks (1926) \\
\hline Megachile angelarum Cockerell & Mo & Mitchell (1941) \\
\hline M. bertoni Schrottky & $\operatorname{Tr}$ & Mitchell (1929) \\
\hline M. chapadiana Mitchell & Mo & Mitchell (1929) \\
\hline M. chrysopidia Smith & Mo & Rayment (1935) \\
\hline M. curvipes Smith & Mo & Mitchell (1941) \\
\hline M. deserta Cockerell & $\operatorname{Tr}$ & Cockerell (1911) \\
\hline M. latimanus Say & Mo & Mitchell (1932) \\
\hline M. cf. leachella Curtis & $\operatorname{Tr}$ & Wolf (1998d) \\
\hline M. gemula Cresson & $\operatorname{Tr}$ & Mitchell (1929) \\
\hline M. maritima (Kirby) & $\operatorname{Tr}$ & Wolf (1993a) \\
\hline M. onobrychidis Cockerell & Mo & Mitchell (1941) \\
\hline M. parallela Smith & $2 \mathrm{Mo}$ & Mitchell $(1929,1941)$ \\
\hline M. peribirta Cockerell & Mo & Mitchell (1929) \\
\hline M. pilidens Alken & $\operatorname{Tr}$ & Wolf (1998b) \\
\hline M. rotundata (Fabricius) & $2 \mathrm{Tr}, \mathrm{Bi}$ & $\begin{array}{l}\text { Akre et al. (1982), } \\
\text { Gerber \& Akre (1969) }\end{array}$ \\
\hline M. subrixactor Cockerell & $\operatorname{Tr}$ & Cockerell (1918) \\
\hline M. tapytensis Mitchell & $\operatorname{Tr}$ & Mitchell (1929) \\
\hline
\end{tabular}


Table 6. (continued) Cases of gynandromorphy reported from Apoidea.

\begin{tabular}{lcl}
\hline \multicolumn{1}{c}{ Species described } & $\begin{array}{c}\text { Gynander } \\
\text { Category }\end{array}$ & \multicolumn{1}{c}{ Reference } \\
\hline M. uniformis Mitchell & $\mathrm{Tr}$ & Mitchell (1929) \\
M. vidua Smith & $2 \mathrm{Mo}$ & Mitchell (1929) \\
M. willughbiella (Kirby) & $\mathrm{Bi}, \mathrm{Tr}$ & Benno (1948), \\
Megachile sp. & $\mathrm{Tr}$ & Mitchell (1929) \\
Osmia aurulenta (Panzer) & $\mathrm{Mo}$ & Wolf (1991a) \\
O. bicolor (Schrank) & $\mathrm{Mo}$ & Wolf (1990) \\
O. caerulescens (L.) & $\mathrm{Mo}$ & Benno (1948) \\
O. pentstemonis Cockerell & $\mathrm{Mo}$ & Sandhouse (1923) \\
O. rufa (L.) & $\mathrm{Tr}$ & Noskiewicz (1923) \\
Trachusa byssina (Panzer) & $\mathrm{Tr}$ & Wolf (1992) \\
\hline
\end{tabular}

$1 \mathrm{Bi}=$ bilateral gynander; $\mathrm{Tr}=$ transversal gynander; $\mathrm{Mo}=$ mosaic gynander.

tissues. This approach would allow discriminating between the process of chromosome elimination on the one hand (where all tissues are expected to be diploid), and alternative processes such as embryonic or polyspermic fertilisation on the other (where tissues can be diploid or haploid). The main limiting factor to run this method is the necessity of applying it on fresh specimens.

Observations of the "female" behaviour of two newly described gynanders provide additional insights on how such teratological individuals behave under natural conditions. The observed gynanders could be considered as originally female like most of described gynanders (Wcislo et al. 2004). These two cases are the first behavioural notes that have ever been published on the behaviour of wild gynander bees under natural conditions.

Acknowledgements. We sincerely thank Dr W. Celary (ISEA, Crakow, Poland), Mr G. Else (NHM, London, United Kingdom), Dr L. de Menten (ULB, Brussels, Belgium), and Mr R. Wahis (FUSAGx, Gembloux, Belgium) for their help and collaboration on this study, as well as for their valuable help in the gathering of the scarce bibliographical resources on the topic. We also acknowledge Prof. S. Aron (ULB, Brussels, Belgium) and Mr Stuart P. M. Roberts (University of Reading, Reading, United Kingdom) for useful comments on the study. H. Hines and T. De Meulemeester provided very useful comments on the manuscript. Financial support was provided by the Fonds pour la formation à la Recherche dans l'Industrie et dans l'Agriculture (FRIA) to NV and by the Fonds National de la Recherche Scientifique for the collecting trip of PR.

\section{Bibliography}

Agate R.J., Grishem W., Wade J., Mann S., Wingfield J., Schanen C., Palotie A., Arnold A. 2003. Neural, not gonodal, origin of brain sex differences in a gynandromorphic finch. Proceeding of the National Academy of Sciences 100: 4873-4878.
Akre R.D., Paul C., Zack R.S., Klostermeyer X.C. 1982. Gynandromorphs of Megachile rotundata (Fab) (Hymenoptera: Megachilidae). Entomological News 93: 85-94.

Andrewes C.H. 1946. Gynandromorphic Halictus tumulorum. The Entomologist's Monthly Magazine 82: 46.

Benno P. 1948. Aantekeningen over bijen en wespen I twee gynandromorphic bijen (Hym. Apidae). Entomologische Berichten 12: 250-251.

Benoist R., Berland L. 1935. Trois cas de gynandromorphisme chez les hyménoptères aculéates. Archives du Muséum d'Histoire Naturelle 12: 435-438.

Berndt K. P., Kremer G. 1983. New categories in the gynandromorphism of ants. Insectes Sociaux 30: 461-465.

Beye M., Moritz R.F.A. 1994. Sex linkage in the honeybee Apis mellifera detected by multilocus DNA fingerprinting. Naturwissenschaften 81: 460-462.

Beye M., Hasselmann M., Fondrk M.K., Page R.E., Omholt S.W. 2003. The gene $c s d$ is the primary signal for sexual development in the honeybee and encodes an SR-type protein. Cell 114:419-429.

Bischoff H., Ulrich W. 1929. Über einen Gynander der Mauerbiene (Chalicodoma muraria Retz.) nebst einigen Bemerkungen über normale Individuen. Zeitschrift für Morphologie und Ökologie der Tierse 15: 213-261.

Boveri T. 1915. Über die Entstehung der eugsterschen Zwitterbienen. Archiv für Entwicklungsmechanik der Organismen 41: 264-311.

Bull J.J. 1980. Sex determination in reptiles. The Quaterly Review of Biology 55: 3-21.

Bull J.J. 1981. Coevolution of haplo-diploidy and sex determination in the Hymenoptera. Evolution 35: 568-580.

Carcasson R.H. 1965. A remarkable gynandrous carpenter bee. Journal of the East Africa Natural History Society and National Museum 25: 75.

Celary W., Wisniowski B. 2001. An interesting case of gynandromorphism in Andrena helvola (L., 1758) (Hymenoptera: Apoidea: Andrenidae). Folia biologica 49: 291-293.

Ciofi C., Swingland I.R. 1997. Environmental sex determination in reptiles. Applied Animal Behaviour Science 51: 251-265.

Cockerell T.D.A. 1911. Descriptions and records of bees. XXXV, Androgynella detersa. Annals and Magazine of Natural History 7: 310-319.

Cockerell T.D.A. 1918. The megachilid bees of the Philippine islands. The Philippine Journal of Science 13: 127-144.

Cook J.M. 1993. Sex determination in the Hymenoptera: a review of models and evidence. Heredity 71: 421-435.

Cook J.M., Crozier R.H. 1995. Sex determination and population biology in the Hymenoptera. Trends in Ecology and Evolution 10: 281286.

Cooper K.W. 1959. A bilaterally gynandromorphic Hypodynerus, and summary of cytologic origins of such mosaic Hymenoptera. Biology of eumenine waps, VI. Bulletin of the Florida State Museum 5: 25-40.

Cowan D.P., Stahlhut J.K. 2004. Functionally reproductive diploid and haploid males in an inbreeding hymenopteran with complementary sex determination. Proceedings of the National Academy of Sciences of the United States of America 101: 10374-10379.

Crozier R.H. 1977. Evolutionary genetics of the Hymenoptera. Annual Review of Entomology 22: 263-288.

Duchateau M.J., Hoshiba H., Velthuis H.H.W. 1994. Diploid males in the bumble bee Bombus terrestris. Entomologia Experimentalis et Applicata 71: 263-269.

Eickwort G.C., Ginsberg H.S. 1980. Foraging and mating behavior in Apoidea. Annual Review of Entomology 25: 421-446.

Enderlein G. 1913. Ein hervorragender Zwitter von Xylocopa mendozana aus Argentinien, Mit einem Verzeichnis aller bisher beobachteten Gynandromorphen Hymenopteren. Stettiner entomologische Zeitung 74: $124-140$. 
Engel M.S. 2007. A lateral gynandromorph in the bee genus Thyreus and the sting mechanism in the Melectini (Hymenoptera: Apidae). American Museum Novitates 3553: 1-11.

Exley E. M. 1976. Notes on flying characteristics of Euryglossa (Xenohesma) bees and how a gynandromorph resolves a taxonomic problem. Journal of the Australian Entomological Society 15: 469-470.

Gerber H.S., Akre R.D. 1969. The external morphology of Megachile rotundata (Fabricius) (Hymenoptera: Megachilidae). Melandria 1: 1-36.

Gordh G., Headrick D. 2001. A Dictionary of Entomology. CABI publishing, New-York, $1032 \mathrm{p}$

Hall D.W., Smith I.C. 1954. Studies in pharaon's ant, Monomorium pharaonis (L.) (9) Somatic mosaics. Entomologist's Monthly Magazine 90: $176-182$

Handschin E. 1935. Beobachtungen an einem Zwitter von Xylocopa confusa Perez. Bulletin de la Société entomologique Suisse 16: 312-317.

Heimpel G. E., de Boer J. G. 2008. Sex determination in the Hymenoptera. Annual Review of Entomology 53: 209-230.

Hicks C.H. 1926. A gynandromorphic bee of the genus Dianthidium. American Naturalist 60: 199-200.

Hohndorf A. 1931. Ein frontaler Zwitter von Halictus tumulorum L. (Hym. Apid). Mitteilungen der deutschen Gesellschaft, E. V. 2: 25.

Hunt G.J., Page R.E. 1994. Linkage analysis of sex determination in the honey bee. Molecular and General Genetics 244: 512-518.

Hunter R.H.F. 1995. Sex determination, differentiation and intersexuality in placental mammals. Cambridge University Press, Cambridge, 310 p.

Janzen F.J., Paukstis G. L. 1991a. A preliminary test of the adaptive significance of environmental sex determination in reptiles. Evolution 45: 435-440.

Janzen F.J., Paukstis G.L. 1991b. Environmental sex determination in reptiles: ecology, evolution, and experimental design. Quarterly Review of Biology 66: 149-179.

Laidlaw W. B. R. 1932. A gynandromorphic form of Bombus, with other notes on bees and wasps in Scotland. Scottish Naturalist 193: 25-27.

Leclercq J. 1953. Un cas extraordinaire de gynandromorphisme chez Halictus sexcinctus (Hym. Apidae). Institut Royal des Sciences Naturelles de Belgique 29: 1-4.

Liebert A.E., Johnson R.N., Switz G.T., Starks P.T. 2004. Triploid females and diploid males: underreported phenomena in Polistes wasps? Insectes Sociaux 51: 205-211.

Lind H. 1968. Nest provisioning cycle and daily routine of behavior in Dasypoda plumipes. Entomologiske Meddelelser 36: 343-372.

Linsley E.G. 1937. The effect of stylopization on Andrena porterae Cockerell. The Pan-Pacific Entomologist 13: 157-158.

Løken A. 1967. A stylopized female of Andrena fucata Smith (StrepsHym). Opscula Entomologica 32: 93-96.

Maa T.C. 1940. On the monstruosity of certain Xylocopa-species (Hymenoptera: Xylocopidae). Lingnan Science Journal 19: 83-85.

Maidl F. 1912. Über einen Fall von lateraler Gynandromorphie bei einer Holzbiene (Xylocopa micans Lep.). Verhandelingen der Koninklijke zoologisch-botanischen Gesellschaft in Wien 3: 19-26.

Michener C.D. 2000. The bees of the world. The Johns Hopkins University Press, Baltimore, 913 p.

Milliron H.E. 1960. A gynandromorphic specimen of Psithyrus fernaldae Fkln. (Hymenoptera: Apidae). Bulletin of the Brooklyn Entomological Society 55: 109-113.

Milliron H.E. 1962. A gynandromorph of Bombus flavifrons Cresson (Hymenoptera: Apidae). Bulletin of the Brooklyn Entomological Society 57: $45-46$

Mitchell T. B. 1929. Sex anomalies in the genus Megachile with descriptions of new species (Hymenoptera: Megachilidae). Transactions of the American Entomological Society 54: 321-383.

Mitchell T. B. 1932. A gynandromorph of Megachile latimanus Say. Journal of the Elisha Mitchell Scientific Society 47: 52-54.
Mitchell T. B. 1941. Some additional intersexes in Megachile (Hymenoptera, Megachilidae). Pan-Pacific Entomologist 17: 165-168.

Morgan T. H. 1916. The Eugster gynandromorph bees. American Naturalist 50.

Morgan T.H., Bridges C. B. 1919. The origin of gynandromorphs, p. 122 in: Contributions to the Study of Drosophila. Carnegie Institution of Washington, Washington.

Morice F.D. 1915. Remarkable Hymenoptera. Proceeding of the Entomological Society of London 3-4: 81-83.

Nilsson G.E. 1987. A gynandromorphic specimen of Evylaeus albipes (Fabricius)(Hymenoptera, Halictidae) and a discussion of possible causes of gynandromorphism in haplo-doploid insects. Notulae Entomologicae 67: 157-162.

Noskiewicz J. 1923. Einige Abnormitäten bein den Apiden. Polskiego Pismo Entomologicznego 2: 1-5.

O'toole C. 1989. Profile of Colletes cunicularius (L.) in the British Isles (Hymenoptera: Colletidae). BWARS Newsletter 1989: 3-7.

Pamilo P., Sundström L., Fortelius W., Rosengren R. 1994. Diploid males and colony-level selection in Formica ants. Ethology Ecology \& Evolution 6: 221-235.

Pérez-Ińigo Mora C. 1982. Sobre dos interesantes casos teratológicos en Apoideos (Hym. Apoidea). Boletin de la Asociacion Espanola de Entomologia 6: 29-31.

Perkins R.C. L. 1914. Two hermaphroditic specimens of Andrena, and a monstrous form of Salius exaltatus Fab. The Entomologist's Monthly Magazine 25: 218-219.

Pintureau B., Chapelle L., Delobel B. 1999. Effects of repreated thermic and antibiotic treatments on a trichogramma (Hym., Trichogrammatidae) symbiot. Journal of applied Entomology 123: 743-483.

Plateaux-Quénu C., Plateau-Quénu L. 1982. Description d'un gynandromorphe d'Evylaeus claceatus (Scop.). Bulletin de la Société entomologique de France 87: 325-332.

Popov V.B. 1937. Gynandromorphism and the effects of parasitic castration in Halictus eurygnathus Blüthgen (Hymenoptera: Apoidea). Izvestia Akademiya Nauk SSSR 1937: 481-494.

Rayment T. 1935. A cluster of Bees. The Endeavour Press, Sydney, 752 p.

Ritsema C. 1881. Gynandromorphic Bombus mastrucatus Gerst. Tijdschrift voor Entomologie 24: 111.

Röseler P. 1962. Über einen Fall von Gynandromorphismus bei der Hummel Bombus agrorum Fabr. Mitteilungen des Badischen Landesvereins fûr Naturkunde und Naturschutz EV 8: 289-303.

Rothenbuhler W.C. 1958. Progress and problems in the analysis of gynandromorphic honey bees. Proceeding of the Tenth International Congress Entomology 2: 867-873.

Sandhouse G.A. 1923. A gynandromorphic bee of the genus Osmia. American Naturalist 57: 569-570.

Saunders E. 1901. Gynandrous specimen of Halictus quadricinctus Fab. Entomologist's Monthly Magazine 12: 278-279.

Schenk U. 1871. Einige Bienen-Hermaphroditen. Stettiner entomologische Zeitung 32: 335.

Schwarz H.F. 1926. North American Dianthidium, Anthidiellum and Paranthidium. American Museum Novitates 226: 1-25.

Schwarz H.F. 1929. A gynandromorphic specimen of Trigona cupira var. rhumbleri (Friese). Journal of the New York Entomological Society 37: 145-151.

Sichel J. 1858. Note sur un insecte hyménoptère hermaphrodite (Bombus lapidarius). Annales de la Société entomologique de France 17: 247-249.

Stenton R. 1909. Gynandromorphism of Megachile willughbiella. The Entomologist's Monthly Magazine 20: 188.

Stöckhert F. 1920. Über einen Fall von frontaler Gynandromorphie bei Bombus lapidarius L. Zeitschrift für wissenschaftliche Insekten-Biologie, Berlin 16: 132-134. 
StöckhertF. 1924. Über Gynandromorphie bei Bienen und die Beziehungen zwischen den primären und sekundären Geschlechtscharakteren der Insekten. Archiv für Naturgeschichte 90: 109-131.

Stouthamer R., Luck R.F., Werren J.H. 1992. Genetics of sex determination and the improvement of biological control using parasitoids. Environmental Entomology 21: 427-435.

Tsuneki K. 1975. A partial gynandromorph appeared in the cuckoo bee Nomada sp. (Hymenoptera, Apidae). Kontyû 43: 173-180.

van Wilgenburg, E., Driessen, G. Beukeboom L.W. 2006. Single locus complementary sex determination in Hymenoptera: an "unintelligent" design? Frontiers in Zoology 3: 1-15.

Wahis R. 1996. Un gynandromorphe d'Anoplius viaticus (Linnaeus) et deux cas de monstruosité chez Priocnemis minuta (Vander Linden) et Priocnemis susterai Haupt (Hymenoptera, Pompilidae). Linzer biologische Beiträge 28: 547-551.

Wcislo W., Gonzalez V.H., Arneson L. 2004. A review of deviant phenotypes in bees in relation to brood parasitism, and a gynandromorph of Megalopta genalis (Hymenoptera: Halictidae). Journal of Natural History 38: 1443-1457.

Wheeler W.M. 1910. A gynandromorphous Mutillid. Psyche 17: 186189.

Whiting P.W. 1933. Selective fertilization and sex determination in Hymenoptera. Science 78: 537-538.

Whiting P.W. 1943. Multiple alleles in complementary sex determination of Habrobracon. Genetics 28: 365-382.

Whiting P.W., Whiting A. R. 1925. Diploid males from fertilized eggs in Hymenoptera. Science 62: 437.

Wolf H. 1982. Ein Zwitter von Andrena potentillae Panzer (Hym., Apidae). Linzer biologische Beiträge 14: 45-46.

Wolf H. 1985. Ein Zwitter von Melitta haemorrhoidalis (Fabricius) (Hym., Apoidea, Melittidae). Linzer biologische Beiträge 17: 493.

Wolf H. 1986. Ein Zwitter von Lasioglossum morio (Fabricius) (Hym., Apoidea, Halictidae). Linzer biologische Beiträge 18: 1-4.

Wolf H. 1987a. Ein Zwitter von Lasioglossum fulvicorne (Kirby) (Hym., Apoidea, Halictidae). Linzer biologische Beiträge 19: 27-28.

Wolf H. 1987b. Zwitter von Sphecodes geofrellus (Kirby) und Sphecodes rufiventris (Panzer) (Hym., Sphecoidea, Apidae). Linzer biologische Beiträge 19: 27-28.

Wolf H. 1989. Zwitter von Andrena haemorrhoa (Fabricius) (Hym., Apidae) und Arachnospila trivialis (Dahlbom) (Hym., Pompilidae). Linzer biologische Beiträge 21: 175-176.

Wolf H. 1990. Zwitter von Andrena fulva (Müller), Lasioglossum lissonotum (Noskiewicz) und Osmia bicolor (Schrank) (Hym., Apidae). Linzer biologische Beiträge 22: 287-290.
Wolf H. 1991a. Zwitter von Sphecodes niger Hagens und Bombus pratorum (Linnaeus) (Hym., Apidae). Linzer biologische Beiträge 23: 525-526.

Wolf H. 1991b. Ein Zwitter von Osmia aurulenta (Panzer) (Hym., Apidae). Linzer biologische Beiträge 23: 393-394.

Wolf H. 1992. Zwitter von Tachysphex pompiliformis (Panzer) (Hym., Sphecidae) und Trachusa byssina (Panzer) (Hym., Apidae. Linzer biologische Beiträge 24: 29-30.

Wolf H. 1993a. Zwitter von Arachnospila anceps (Wesmael) (Hym., Pompilidae), Andrena fulva (Müller) und Megachile maritima (Kirby) (Hym., Apidae). Linzer biologische Beiträge 25: 123-125.

Wolf H. 1993b. Zwitter von Andrena barbilabris (Kirby) und Bombus pascuorum (Scopoli). Linzer biologische Beiträge 25: 785-786.

Wolf H. 1994a. Ein Zwitter von Sphecodes albilabris (Fabricius) (Hymenoptera, Apidae). Linzer biologische Beiträge 26: 191-193.

Wolf H. 1994b. Ein Zwitter von Andrena humilis Imhoff (Hym., Apidae). Linzer biologische Beiträge 26: 905.

Wolf H. 1995a. Zwitter von Anthophora furcata (Panzer), Dasypoda hirtipes (Fabricius), Halictus tumulorum (Linnaeus), und Evagetes fibbulus (Lepeletier) (Hymenoptera, Apidae, Pompilidae). Linzer biologische Beiträge 27: 423-425.

Wolf H. 1995b. Zwitter von Andrena humilis Imhoff und Pterocheilus phaleratus (Panzer) (Hymenoptera, Apidae, Eumenidae). Linzer biologische Beiträge 27: 901-903.

Wolf H. 1997. Zwitter von Nomioides minutissimus (Rossi) und Priocnemis schiodtei Haupt (Hymenoptera, Apidae, Pompilidae). Linzer biologische Beiträge 29: 369-371.

Wolf H. 1998a. Ein Zwitter von Anthidium strigatum (Panzer) (Hymenoptera, Apidae). Linzer biologische Beiträge 30: 233-234.

Wolf H. 1998b. Ein Zwitter von Megachile pilidens Alfken (Hymoptera, Apidae). Linzer biologische Beiträge 30: 245.

Wolf H. 1998c. Ein Zwitter von Andrena praecox (Scopoli) (Hymenoptera, Apidae). Linzer biologische Beiträge 30: 247.

Wolf H. 1998d. Ein Zwitter von cf. Megachile leachella Curtis (Hymenoptera, Apidae). Linzer biologische Beiträge 30: 613.

Wolf H. 1999. Zwitter von Odynerus spinipes (Linnaeus) und Coelioxys inermis (Kirby) (Hymenoptera, Eumenidae, Apidae). Linzer biologische Beiträge 31: 801-802.

Wolf H. 2000. Ein Zwitter von Epeolus julliani Pérez 1884 (Hymenoptera, Apidae). Linzer biologische Beiträge 32: 1321-1322.

Wolf H. 2001. Bemerkungen zu Zwittern unter den Stechimmen (Hymenoptera: Aculeata). Linzer biologische Beiträge 33: 579-581.

Zayed A., Packer L. 2001. High levels of diploid male production in a primitively eusocial bee (Hymenoptera: Halictidae). Heredity 87: 631636. 